\title{
Mi a közösségi informatika, és miért fontos?
}

A tanulmány bevezetést nyújt a közösségi informatika (KI) szakterületének megismeréséhez. A szerző meghatározása szerint a közösségi informatika az IKT olyan, közösségi célok elérése érdekében történő alkalmazását és fejlesztését jelenti, ami túlmutat a „digitális szakadék“ problematikáján, és magába foglalja az IKT hozzáférhetővé és hasznosan alkalmazhatóvá tételét a helyi gazdasági fejlődés, a társadalmi igazságosság és a politikai részvétel elősegítésére a kirekesztett csoportok körében. A KI másfajta stratégiákat kíván meg, mint az egyéni számítógép-használat, illetve internet-elérés. Elsősorban a fejlődő országok igényeihez alkalmazkodik, de a fejlett országokban is kívánatos lehet, főként a társadalom szegényebb és marginalizált rétegeiben, az idősek körében vagy a távoli vidéki területeken élő közösségek esetében. A KI igényt tarthat az IKT szakembereinek és tudományos kutatóinak, valamint mindazoknak az érdeklődésére, akik a közösségi alapú információs technológiákkal foglalkoznak. Kapcsolatot teremt az egyik oldalról a tudományos elméletek és a kutatás, a másik oldalról pedig a ma globális szinten tízezer-számra működő közösségi hálózatok, közösségi technológiai központok, teleközpontok, közösségi kommunikációs központok és teleházak tapasztalatai alapján felmerülő gyakorlati és politikai kérdések között.

Kulcsszavak: közösségi informatika, információs és kommunikációs technológia (IKT), közösségi folyamatok, digitális szakadék, lokális gazdasági fejlődés, társadalmi igazságosság, politikai cselekvőképesség, internet, információs rendszerek, vezetői információs rendszerek, közösségi hálózatok

\section{Szerzői információ:}

Michael Gurstein

szociológus Kanadában végezte tanulmányait, majd a Cambridge-i Egyetemen doktorált szociológiából. Jelenleg a vancouveri közösségi informatikai kutatási, fejlesztési és képzési központ ügyvezető igazgatója, a Fokvárosi Múszaki Egyetemen múködő Információs Társadalom Intézet egyik igazgatója és a New Jersey Institute of Technology kutató professzora. A közösség informatikáról Community Informatics: Enabling Communities with Information and Communications Technologies címmel írt könyve indította meg e szakterület kifejlődését. Tagja volt a vancouveri Közösségi Hálózatnak és a Brit Columbia tartományban létrejött közösségi hálózatok egyesületének, részt vett a Global Community Networking Partnership nevú szervezet vezetốségének munkájában. A Journal of Community Informatics címú folyóirat fốszerkesztôje.

Így hivatkozzon erre a cikkre:

Michael, Gurstein. „Mi a közösségi informatika, és miért fontos?”. Információs Társadalom VIII, 2. szám (2008): 17-36.

$\Longrightarrow$ https://dx.doi.org/10.22503/inftars.VIII.2008.2.2

A folyóiratban közölt müvek

a Creative Commons Nevezd meg! - Ne add el! - Így add tovább! 4.0

Nemzetközi Licenc feltételeinek megfelelöen használhatók. 
Michael Gurstein

\section{Mi a közösségi informatika, és miért fontos?}

\section{Mi a közösségi informatika (Community Informatics)??}

Kulcssæavak: közösségi informatika, információs és kommunikációs technológia (IKT), közösségi folyamatok, digitális szakadék, lokális gazdasági fejlődés, társadalmi igazságosság, politikai cselekvóképesség, internet, információs rendszerek, vezetói információs rendszerek (Management Information Systems, MIS), közösségi hálózatok.

A közösségi informatika (KI) azon a feltételezésen alapszik, hogy a földrajzilag meghatározott, „fizikai” értelemben együtt éló közösségeknek olyan jellegzetességeik, igényeik és lehetôségeik vannak, amelyek az IKT terjesztése és fejlesztése terén másfajta stratégiákat kívánnak meg, mint az egyéni vagy otthoni számítógép-használat, illetve internetelérés általánosan elfogadott és alkalmazott modelljei. A közösségi informatika az IKT olyan alkalmazását és fejlesztését jelenti, ami elsôsorban a fejlődő országok igényeihez alkalmazkodik, de a fejlett országokban is kívánatos lehet, fóként a társadalom szegényebb és marginalizált rétegeiben, az idốsek körében vagy a távoli vidéki területeken élố közösségek esetében.

A KI igényt tarthat az IKT szakembereinek és tudományos kutatóinak, valamint mindazoknak az érdeklődésére, akik a közösségi alapú információs technológiákkal foglalkoznak. Kapcsolatot teremt az egyik oldalról a tudományos elméletek és a kutatás, a másik oldalról pedig a ma globális szinten tízezerszámra múködő közösségi hálózatok (Community Networks), közösségi technológiai központok (Community Technology Centres), teleházak (Telecentres), közösségi kommunikációs központok (Community Communications Centres) és teleházak (Telecottages) tapasztalatai alapján felmerüló gyakorlati és politikai kérdések között.

A KI valódi kihívás az olyan múszaki szakemberek számára, akik a mindennapi életük technológiai eszközökkel történó jobbítására törekvő hátrányos helyzetú csoportok igényeit tartják szem elốtt. Ugyanakkor tág teret nyit azok elótt a tudósok és tudományos kutatók elốtt, akik túl kívánnak lépni a saját szúkebb, gyakran önmagukba forduló tudományáguk határain, és érdeklôdésük az olyan módszerekre és megoldásokra irányul, amelyek révén a technológiai eszközök mind a fejlett, mind a fejlődő világban közvetlenül felhasználhatók az emberek életfeltételeinek és életesélyeinek jobbítására. Végül a KI közvetíti a politikusokhoz annak a szükségességét, hogy fel kell ismerniük: az információs és kommunikációs technológiák (IKT) különféle módokon lehetôvé teszik a kormányzás, az önszerveződés és az önigazgatás új módszereinek kialakítását. A KI ugyanis jelezni képes számukra a közösségek szükségleteit, melyek alapján a

${ }^{1}$ Az alábbiakban Michael Gurstein nagyobb terjedelmú, frissen publikált könyvéból közlünk részleteket: Michael Gurstein 2007. What is Community Informatics (and Why Does It Matter)? Milan, POLIMETRICA.

${ }^{2}$ Adaptálva Michael Gurstein Community Informatics: Current Status and Future Prospects - Some Thoughts címen a Community Technology Reviere 2002. téli-tavaszi számában megjelent tanulmányából. 
megfelelő eszközök biztosításával hatékonyan válaszolhatnak a lehetôségek tudatában a hátrányos helyzetứ közösségekben is felmerüló igényekre és alulról jövő kezdeményezésekre.

A közösségi informatika elmélete és gyakorlata fokozatosan fejlődik. Ez a fejlődés részben a közösségi hozzáférés és a közösségi hálózatok tapasztalatain alapul, részben pedig az a felismerés, hogy a hozzáférés önmagában nem elegendô - inkább arról van szó, hogy a hozzáférés megteremtésével mire lehet azonnal vagy a jövóben célszerúen és hatékonyan alkalmazni az IKT máris rendelkezésre álló vagy késóbb elérhetôvé váló eszközeit. A KI fejlődése biztosítja a helybeli civil szerveződések és az „állami” szféra egyidejú jelenlétét az egyre inkább elüzletiesedő hálózati környezetben, s egyben alapot nyújt elsősorban a helyi innovációk támogatásához, mivel a helyi közösségeknek is alkalmazkodniuk kell a technológiai változásokhoz, a termelés globalizálódásához és a versenyhez. re épít:

A KI - meglátásom szerint - többek között az alábbi, egymást átfedő előzmények-

- az információs rendszerek kiépítésével és alkalmazásával kapcsolatos szervezetelméleti eredmények;

- a szervezeti célokat támogató vezetôi információs rendszerek kidolgozása és fejlesztése;

- a bizonyos normatív célok elérését (ebben az esetben az IKT felhasználása révén) megvalósítani kívánó világméretú társadalmi aktivizmus;

- a közösségek életét felélénkítố közösségfejlesztés folyamatai, amelyek képessé teszik a közösségeket az önszerveződésre és önigazgatásra;

- a közérdek érvényesülését biztosító politikai és közigazgatási eszközök (elsôsorban állami programok) tanulmányozása és fejlesztése;

- az IKT-nak a társadalmi és gazdasági fejlődés szolgálatába állítására irányuló „IKT a fejlődésért” mozgalom és egyéb fejlesztési programok;

- a szolgáltatástervezés mint a leghatékonyabb módok meghatározása bizonyos igények (ebben az esetben közösségi szükségletek) kielégítésére, különös tekintettel az IKT felhasználási lehetőségeire.

Mindezek az előzmények különféle megközelítésekkel, más-más történeti háttérrel alakultak ki, és eltérô módszereket alkalmaznak. Valójában a tényleges megvalósítás és a gyakorlati alkalmazás folyamatán keresztül olvadnak össze a KI körébe tartozó tevékenységekké, egy olyan társadalmi folyamat részeiként, amelyben interakcióba lépnek egymással, és érzékenyen reagálnak az adott társadalmi környezet igényeire, miközben változatos lehetôségeket kínálnak a problémák megoldására, és sokrétú adaptációs folyamatokat váltanak ki.

\section{Milyen szerepet játszik a KI az információs vagy hálózati társadalomban?}

Az információs társadalom fejlődése során a társadalom különféle elemei, múködési folyamatai és intézményei átstrukturálódnak. A változások egy részét bizonyos értelemben a digitális technológiák nyújtotta lehetôségek idézik elô. Ez az átrendezốdés 
azonban nem véletlenszerúen és nem érdekektól mentes módon megy végbe. Az információs társadalom fejlődése általában olyan struktúrákat hoz létre, amelyek tovább gazdagítják és újabb eszközökkel ruházzák fel azokat, akik máris rendelkeznek a szükséges forrásokkal (és intelligenciával) ezeknek a folyamatoknak a kezeléséhez és irányításához. Így például azok, akik olyan helyzetben vannak, hogy megengedhetik maguknak az IT rendszerek kiépítését és alkalmazását nagyszabású üzleti vállalkozásaik támogatására, képesek ezeket a fejleményeket a saját érdekeik szolgálatába állítani más érdekek háttérbe szorításával.

A vezetôi információs rendszereket például nem a dolgozók, az ügyfelek vagy más lehetséges „érintettek” érdekében, hanem kifejezetten a vállalati munkaszervezés hatékonyabbá tételére fejlesztették ki, hogy lehetốvé tegyék a források optimális allokációját és ellenốrzését, beleértve természetesen az információs technológiák felhasználása révén megszerezhető információs forrásokat is. Ennek a jelentôségét gyakran szem elól tévesztik, mivel az információs rendszerek szokásos megközelítési módja ezeket inkább semleges, vagyis érdekmentes eszközként tünteti fel, nem pedig olyan mátrixként, amelyben a hatalom gyakorlása történik az intézményi struktúrákon belül. A közösségi informatika jelentôsége ebben a kontextusban abban áll, hogy cselekvési lehetôségeket nyújt azoknak is, akik általában nincs hatalmuk ezekben a rendszerekben.

Így tehát hasznosabb lehet, ha a kérdést nem az „információs társadalom”, hanem inkább a „hálózati társadalom” dimenziójában vizsgáljuk, arra a módra koncentrálva, ahogyan az IKT meggyorsítja a gazdasági-társadalmi (és politikai) rendszerek átstrukturálódását, beleértve a hatalmi viszonyokat is, és nem az ilyen rendszerek tartalmára, vagyis az „információra” helyezzük a hangsúlyt, ahol az effajta átrendezódés kevésbé válik azonnal láthatóvá. Ebben a megközelítésben természetesen Castells gondolatmenetét követjük, aki a „hálózatokat” tekinti a digitalizált társadalom és gazdaság domináns, mindent átható strukturális jegyének, noha más megállapításaink és következtetéseink ebben a tekintetben meglehetôsen eltérnek Castells álláspontjától.

A hálózati társadalom fogalmán itt olyan társadalmat értünk, amelyben a termeléși viszonyok kialakulóban levố, de (még) nem domináns struktúráit az IKT közvetítésével létrejött hálózati kapcsolatok alkotják. Ebben a kontextusban a hálózatok és a hálózati kapcsolatok, amelyek szükségképpen az IKT révén jönnek létre, mindenre kiterjedő transzformáló hatást fejtenek ki az egyes hálózatokon belül, illetve azok között megvalósuló tranzakciók és interakciók valamennyi aspektusára.

A hálózati társadalom olyan társadalom, amely nem az olyan, személyes érintkezésre épülő́ hagyományos rendszerekre támaszkodik, mint amilyeneket például a családok alkotnak, hanem nyitott és igen nagy kiterjedésú hálózati struktúrák és összeköttetések alapján folyamatosan újjáformálja önmagát. Ebben az értelemben a hálózat fogalma bizonyos mértékig szembeállítható a közösség fogalmával. A hálózatok ugyanis rendszerint autonóm, önmagukat irányító egyéni aktorok (hálózati terminológiával: csomópontok) kapcsolatai alapján szervező́dnek, vagyis alapvető strukturáló elvük a más egyénekkel (csomópontokkal) interakcióba lépó egyének (csomópontok) együttmúködése, ami többnyire valamilyen kommunikációs eszköz közvetítésével és minden esetben egyéni döntések szerint valósul meg. A hálózat és a közösség közötti különbség abban ragadható meg, hogy a közösségek viselkedésére ezzel szemben az egységes fellépés 
jellemző, amit a közösen vállalt értékek, normák és viselkedési minták, valamint a közös célok határoznak meg.

A közösségek szerepe a hálózati társadalomban abban nyilvánul meg, hogy a javak szélesebb körre kiterjedố megosztása és kollektív hasznosítása érdekében bizonyos kreatív, dialektikus feszültséget teremtenek, mintegy ellenpontozva az egyénekre alapozott „,hálózatok” múködését. Ilyen értelemben a technológiai eszközöknek a „közösségek" támogatása érdekében történő alkalmazását szorgalmazó közösségi informatika felfogása és elemzési módszere ellentétben áll a jelenleg domináns szemlélettel, amely szerint a technológiai eszközök révén létrejövố hálózatok olyan - egymással összeköttetésben álló - egyénekból tevő́dnek össze, akiket csupán kvázifüggetlen csomópontként betöltött pozíciójuk kapcsol össze egymással.

A hálózati társadalom jelenlegi konvencionális értelmezése szerint ezt az ellentétet néha úgy interpretálják, hogy a „hálózatok” technológiai úton jönnek létre, míg a „közösségek" társadalmi és emberi kapcsolatokon alapulnak. Az információs technológia azonban valójában sok esetben ugyanolyan fontos szerepet játszhat a közösségek kialakításában és azok lehetôségeinek kibővítésében, mint a hálózatokban összekapcsolódó egyének (csomópontok) érdekeinek szolgálatában. A közösségek lehetôségeinek ilyen értelemben való kiterjesztése a közösségi informatika révén tehát nem más, mint az a folyamat, melynek során a közösség az IKT-eszközök felhasználásán keresztül „informatizálódik", miközben az információs technológia az egyes közösségek közötti vagy azokon belüli összeköttetések létrejöttének elősegítôjévé és a kapcsolatok hordozójává válik. Ezek a közösségek éppen olyan hatékonysággal szerveződhetnek és formálódhatnak IT-platformon, az IKT segítségével, mint a hagyományos, nem az IKT közvetítette kapcsolatok révén: ebben az esetben az IKT éppen olyan, a lehetôségeket kiterjesztô szerepet játszik a közösségek életében, mint amilyet - általánosabban elismert módon - az egyénekre alapozott hálózatokban betölt.

\section{A közösségi informatika szemben áll-e a hálózati individualizmussal, vagy azzal párhuzamba állítható?}

Barry Wellman és munkatársai ${ }^{3}$ az elektronikus hálózatokban összekapcsolódó egyének státusának és egymáshoz való viszonyának jellemzésére a „hálózati individualizmus” ${ }^{4}$ kifejezést vezették be. Erre példaként a Wal-Mart áruházlánc dolgozóit mutatják

${ }^{3}$ B. Wellman - A. Quan-Haase - J. Boase - W. Chen - K. Hampton - I. I. de Diaz - K. Myata: The Social Affordances of the Internet for Networked Individualism. Journal of Computer Mediated Communication, 8, 3.

${ }^{4}$ Van Dijk a következố igen hasznos magyarázattal szolgál Wellman elméletéhez: ez annyit jelent, hogy a legfontosabb csomópont a hálózatban nem valamilyen speciális hely, csoport vagy szervezet, hanem az egyén, az általa játszott szerepek egyikében. Az individualizálódás társadalmi és kulturális folyamatát hathatósan támogatja a társadalmi és médiahálózatok kialakulása. Ezek felhasználásával az egyén igen mobilis életstílust alakít ki, amit földrajzilag igen erôsen szétszórt, gyakran egymást keresztezố kapcsolatok jellemeznek. Minden mobiltelefon-felhasználó tudja, hogy amikor telefonál, többé nem egy bizonyos hellyel létesít kapcsolatot, hanem egy bizonyos személlyel, annak valamelyik szerepében. Ez a gyakorlat igen felszabadító lehet, és sok mindenre lehetốséget nyújthat, de van egy kevésbé pozitív oldala is. Egyre kevesebb ember lát bennünket teljes személyiségünkben: személyiségünknek mindig csupán az egyik vagy csak néhány oldalát 
be, akiknek a viselkedésében - noha ennek nincsenek tudatában - az individualizmus olyan formája jelenik meg, ami korábban teljesen ismeretlen volt a vezetók és az alkalmazottak közötti kapcsolatokban. Ez a jelenség azért alakulhatott ki, és az efféle struktúrák azért tünnek erốteljesnek az egyéni alkalmazottakhoz viszonyítva, mert a munka összehangolását és szervezését többé nem közvetlenül egy-egy menedzser, illetve a vállalati vezetốség látja el, hanem maga az elektronikus infrastruktúra, a „hálózat” biztosítja a munkatevékenységek koordinálását és rendszerbe állítását, beleértve az egyéni munkateljesítmények integrációját a szélesebb vállalati és adminisztratív struktúrába. ${ }^{5}$

Wellman felfogása a „hálózati individualizmusról”, melynek révén az identitás a „hálózati” társadalomban manifesztálódik, igen hasznos annyiban, hogy ráirányítja a figyelmet egyrészt arra, hogy a hálózat közvetlenül képes kapcsolatot teremteni az egyénnel, másrészt pedig arra is, ahogyan az egyén „megéli” a szétszórt és az ő szemszögéból központ nélkülinek túnố hálózatot, és közvetlenül együttmúködik vele társadalmi csoportosulások vagy más társadalmi konstrukciók közvetítése nélkül. Megadja továbbá azt az érzést, hogy az egyén - egy olyan környezetben, amelybe elektronikus úton létesített többszörös összeköttetések útján kapcsolódik bele - egyszersmind olyan konstrukció, amely a széttöredezett individuális identitásokat új struktúrákba szervezi az egymást csupán részlegesen (ha egyáltalán) átfedő hálózatokon belül, azok múködésére reagálva. Így az Én megalkotása ebben a kontextusban az egyéni akarat olyan aktusaként értelmezhetô, ami a különböző egyének, sốt a különféle alkalmak esetében is más-más formákat ölthet. ${ }^{6}$

Ebból következốen belátható, hogy az egyéni cselekvés ezen a kontextuson belül már nem társadalmi környezetben történik, hanem azokon az egyedi hálózatokon belül, illetve rajtuk keresztül, ahol az Én képes (vagy elérhetố) a másokkal való interakcióra, de csupán a kapcsolatoknak vagy az összeköttetéseknek azon az erósen korlátozott területein, amelyeket az adott hálózat kínál. Ennek egyik példájaként egy egyéni játékos, aki részt vesz az igen sok szereplốs hálózati játékokban (Massively Networked MultiPlayer Games, $M M P G$ ), képes interakcióba lépni játékostársaival, és „cselekedni” a játékon belül, de csak olyan módon és olyan múveleteket végrehajtva, amelyeket elôírnak és pontosan körülhatárolnak a hálózat konkrét paraméterei és a játékszabályok (vala-

mutatjuk meg, ami éppen egy bizonyos szerepet játszik (Wellman 2000). Jelenleg az utolsó menedéket jelentô családi háztartás, ahol még feltételezhetố, hogy teljesebben megismerjük egymást, szintén felbomlóban van. A családokban a férjek és a feleségek, a szülók és a gyermekek egyre jobban elkülönülố tevékenységekben vesznek részt, más-más társadalmi és médiahálózatokban. Ennek megfigyelhetố hatásaként fokozódhat a magányosság, az elidegenedés, a bizonytalanság és a másoktól való meg nem értettség érzése. Ez megtörténhet a rendelkezésre álló kommunikációs eszközök virtuális robbanásszerú gyarapodása dacára vagy éppen ennek következtében. http://www.gw.utwente.nl/vandijk/research/network_theory/network_theory_plaatje/a_ theory_outline_outline_of_a.doc/

${ }^{5}$ Itt és más területeken, ahol a centralizált döntéshozatalon alapuló, külsóleg irányított hálózatokkal foglalkozunk, közvetlen analógiaként meg kell említenünk a közigazgatási szolgáltatások elektronikus formára való átalakítását (e-Government), ami anélkül megy végbe, hogy vele párhuzamosan biztosítanák azokat a fejlett eszközöket is, amelyek elôsegítenék az állampolgári részvételt és ellenórzést az ilyen szolgáltatások helyi közösségi szintjén (e-Governance). E kérdés részletesebb kifejtését illetốen lásd M. Gurstein - D. Schauder W. Taylor 2005. E-Governance and E-Government. International Conference on Engaging Communities. Brisbane, Australia, July.

${ }^{6}$ B. Wellman - K Hampton 1999. Living Networked in a Wired World.Contemporary Sociology, Vol. 28. No. 6. 
mint a játékban önkényesen definiált identitások). Hasonlóképpen az az egyén, aki vesz vagy elad az eBay hálózaton, kereskedelmi tranzakcióit csupán az egyének közötti interakciókban definiált paraméterek között hajthatja végre, az eBay rendszeren belül kialakított „profiljának”, továbbá az eBay által előírt és technológiai eszközökkel érvényesített interakciós szabályoknak vagy „,politikának” megfelelően. ${ }^{7}$

Az identitás fogalma - és ezen keresztül a „hálózati individuumként” végzett egyéni akció - ily módon speciális formát ölt. Az egyén - jellemzố „profiljának” megadásával - meghatározhatja a saját speciális „identitását” az adott hálózat kontextusában, ám az a mód, ahogyan ez a bizonyos identitás végrehajtja a maga akcióit a hálózaton belül, közvetlenül függố viszonyba kerül az adott hálózat „törvényeitól”, a központilag meghatározott és előírt szabványoktól és szabályoktól. ${ }^{8}$ Az egyén kontrollálhatja a saját profilját (identitását), de ezt csupán olyan szabályok keretei között teheti meg, amelyekre nem gyakorolhat közvetlenül hatást. Ezeket csak annak a kockázatával hagyhatja figyelmen kívül vagy utasíthatja el, hogy kizárják a hálózatból, és így többé nem kapcsolódhat be, sốt kitörlódik a hálózat résztvevớinek sorából, ami - hálózati terminológiával - egyenértékú a megsemmisítéssel: nem csupán az adott identitás elpusztítását vagy lerombolását jelenti, amikor jelenlétének a nyomai még fennmaradhatnának a hálózaton belül, hanem teljes mértékben megsemmisül, részvételének minden nyoma, töredéke vagy maradványa véglegesen törlődik a hálózatból. ${ }^{9}$

A „hálózati individualizmus” Wellman-féle modelljében az egyetlen ontológiailag meghatározott mozgatóerố (a független cselekvés független ügynöke vagy forrása) maga a hálózat. Wellman megfogalmazásában az egyén nem más, mint az adott személy különféle olyan - külsóleg irányított termelési, fogyasztási, sớt társadalmi - hálózatokban való részvételének összege, amelyeknek a tagja, vagy amelyekkel szerződéses kapcsolatokban áll. Ebben a világban a hálózat jelent mindent.

A valóságos világban azonban a külsóleg irányított hálózat csak az egyik eleme a valóságnak. Ezen túlmenóen vannak olyan önszerveződő és egyéni kezdeményezésekre épülố részvételi hálózatok is, amelyekhez az egyén nem identitásának bizonyos töredékei, hanem teljes személyiségével, önállóan kezdeményezett és választott identitása alapján csatlakozik. Ezek az akár fizikai, akár virtuális kapcsolatokon alapuló hálózatok „közösségekként” múködnek, és ezeken keresztül akciókat lehet végrehajtani, különféle törekvéseket és programokat lehet megvalósítani, szembenézve a valósággal, ami mindezek révén módosítható.

\footnotetext{
${ }^{7}$ http://pages.ebay.com/help/policies/hub.html?ssPageName=home:f:f:US

${ }^{8}$ Lásd azt a rendkívül érdekes vitát, ami kialakulóban van a „kód mint törvény” fogalmával kapcsolatban, például Lawrence Lessig elektronikus formában publikált könyvében: Code and other Laws of Cyberspace. http://www.code-is-law.org

${ }^{9}$ Az eBay rendszerében az a személy, akit kizárnak vagy felfüggesztenek, elveszíti a tagsággal járó valamennyi elôjogát. A felfüggesztett egyénnek semmilyen létezố címéról nincs joga részt venni az eBay portálon lebonyolított tranzakciókban, és új felhasználóként sem regisztrálhat. A felfüggesztés lehet meghatározott idejú, meghatározatlan idejú vagy végleges. A felfüggesztés mindaddig hatályban marad, amíg az eBay meg nem szünteti (http://pages.ebay.com/help/policies/rfe-previously-suspended.html). Felmérések szerint jelenleg körülbelül 250 ezer személy és vállalkozás megélhetése legnagyobbrészt az eBay portálon végrehajtott tranzakciókra van alapozva. Így tehát a fentiek szerinti felfüggesztés - a tiltakozás vagy fellebbezés joga nélkül potenciálisan rendkívül jelentốs szankció, és óriási gazdasági és társadalmi hatalmat ad azoknak a kezébe, akik ezeket a szabályokat érvényesítik.
} 
Ezeknek a fizikailag, illetve elektronikus úton létrejövő „közösségeknek” a léte a Wellman által leírt „hálózati” ontológiával strukturálisan ellentétes elveken alapul. Ezek ugyanis egy módositható valóság alapjaként vagy alapvetố elemeiként jönnek létre, és olyan szervezeti, gazdasági és társadalmi struktúrák rendszerét alkotják, amelyek a központilag irányított és ellenôrzött hálózatoktól függetlenül múködnek. Képesek szembeszállni a Wellman által tárgyalt individualizált és ugyanakkor központosított hálózatokon keresztül létrehozott (mesterségesen reprodukált és kiterjesztett) struktúrákkal, másfajta valóságot hozva létre, mint amit a Wal-Mart, a Microsoft és a hozzájuk hasonló más nagyvállalati aktorok teremtenek meg.

Az a következtetés, hogy az ilyen - akár elektronikus úton, akár fizikailag létrejött közösségeknek független és önmagában megalapozott ontológiai státusa van, azért jelentôs, mert a „közösségeket” a társadalomtudományi és technikai szakirodalom nagy részében az egyénekhez, csoportokhoz vagy vállalatokhoz és intézményekhez képest másodrendú tényezóknek tekintik. Azt állítjuk, hogy a „közösségek” önmagukban megálló, primordiális entitásnak és szilárd platformnak tekinthetók, melyre konceptuális bázisként támaszkodva az ember technikai alkotótevékenységet végezhet (és ezt meg is kell tennie), például a hardver- és szoftvertervezés területén. ${ }^{10}$ Ily módon lehetôség nyílik - és ez képezi a „közösségi” informatika konceptuális alapját - olyan információs, kommunikációs és hálózati rendszerek létrehozására, amelyek biztosíthatják az eszközöket a közösségek „hatóerejének" fokozására és a világban való cselekvóképességének megteremtésére, hasonló módon ahhoz, ahogyan az információs és kommunikációs technológiákat, illetve a hálózatokat a „nagyvállalatok” vagy az „egyének” felhasználják múködésük hatékonyságának fokozására. Ilyen értelemben tehát az IKT mint új, nagyobb lehetőségeket nyújtó erôforrás felhasználásával a helyi közösségek is aktívan beilleszkedhetnek a tágabb világba.

A gyakorlatban ez annyit jelent, hogy az egyéneket összekapcsoló, vagyis közösségalkotó (kollaborációs) követelmények bizonyos koordináló és integráló kiindulási alapként használhatók a hardver-, szoftver- és hálózattervezésben. Így természetes módon valósulhatnak meg a közösségi IKT-alkalmazások, jelentốs eltérésekkel a menedzsment vagy általában a vállalatok hatékonyságának növelésére kifejlesztett információs és technológiai rendszerektól. ${ }^{11}$

\section{Mi a különbség a közösségi informatika és a társadalmi informatika között?}

A közösségi informatika és a társadalmi informatika közötti kapcsolatról viták folynak. A társadalmi informatika (Social Informatics, SI) fogalmát általában a Rob Kling és munkatársai által az Indianai Egyetem Társadalmi Informatikai Központjában végzett munkához társítják. Kling a „társadalmi informatikát” a következóképpen definiálta:

${ }^{10}$ Special Issue on CI and Systems Design 2007. Journal of Community Informatics, Vol 3. No. 1.

${ }^{11}$ M. Gurstein - T. Horan 2005. Why Community Information Systems Are Important to the Future of Management Information Systems and The Field of Information Science (IS)? (Miért fontosak a közösségi információs rendszerek a vezetối információs rendszerek [MIS] és általában az információtudomány [IS] jövốje szempontjából?) The Gordon Davis Series on the Future of Information Systems Academic Disciplin: Opportunities and Directions. 
„Azoknak a kutatásoknak és tanulmányoknak az összessége, amelyek a számítógépesítés társadalmi aspektusait vizsgálják, beleértve az információs technológiának a társadalmi és szervezeti változásokban játszott szerepét, az információs technológiák társadalmi kontextusokban történố felhasználását, valamint azokat a módokat, ahogyan az információs technológiák társadalmi szervezôdését a társadalmi erók és a társadalmi berendezkedések befolyásolják." 12

A fenti meghatározás alapján a közösségi informatika (KI) az alábbiakban különbözik a társadalmi informatikától (TI):

a) a TI elsôsorban a jelenségek „kutatásával és tanulmányozásával” foglalkozik, míg a KI középpontjában az IKT „,társadalmi” kontextusban való felhasználásának „gyakorlata” (valamint annak kutatása) áll;

b) a TI a „társadalomnak”, illetve a számítógépesítés „szociális aspektusainak” igen általános és meglehetôsen absztrakt kategóriájával foglalkozik, míg a KI érdeklődése arra irányul, hogy az IKT felhasználása hogyan valósul meg konkrétan azonosítható közösségekben;

c) a KI egyebek között az IKT alkalmazásait konkrét társadalmi-közösségi kontextusokban (például az egészségügy, a gazdasági fejlődés és az oktatás terén) vizsgálja, míg a TI vizsgálódásai az általánosabb társadalmi vagy szervezeti rendszerszintre irányulnak;

d) a KI közvetlenül foglalkozik az IKT felhasználásához szükséges hardverek és szoftverek megtervezésével és fejlesztésével (és közvetlenül érdekelt az alkalmazásokban), míg a TI csekély érdeklődést látszik mutatni az IKT tervezési és fejlesztési aspektusai iránt; továbbá

e) a KI „aktivista” módon közelíti meg a tárgyát (nem csupán tanulmányozva azt, hanem aktív részvétellel az IKT világának megváltoztatásában), míg a TI megelégszik azzal, hogy egyszerúen megkísérelje leírni és megérteni az általa vizsgált jelenségeket.

Egyesek néha azt állítják, hogy a KI a TI egyik „,alrendszere”, de én a magam részéról nem hiszem, hogy ez igaz lenne. A KI gyakorlati komponense határozottan megkülönbözteti a KI által célba vett problematikát a TI vizsgálódásainak tárgyától, noha bizonyos mértékú átfedés van a két irányzat „tárgya”, illetve „kutatási területe” között. A kettố összezavarásának természetesen fennáll a lehetôsége, mivel a társadalmi struktúrák és társadalmi folyamatok informatikai megközelítése bizonyos mértékig párhuzamos a közösségi struktúrák és közösségi folyamatok informatikai megközelítésével, és ugyanígy világos kapcsolat áll fenn a kettô között, ami odáig terjedhet, hogy a közösségi struktúrák és közösségi folyamatok bennfoglaltatnak a tágabb társadalmi struktúrák és társadalmi folyamatok körében. Úgy vélem azonban, hogy az informatika kifejezés használata, ahogyan az a „társadalmi informatika” frazeológiájában történik, valójában téves lehet. Nehezen tudom megérteni, hogy mi lehet a társadalmi informatika bármilyen konkrét alkalmazása. Számomra érthető az informatikai eszközöknek a „társadalmi hálózatépítés" vagy a társadalmi szolgáltatások terén történő alkalmazása, de a társadalmi informatikához - legalábbis a konkrét alkalmazások szintjén - nem tudok világosan felismerhető tárgyat vagy azonosítható példát társítani.

\footnotetext{
${ }^{12}$ http://rkcsi.indiana.edu/
} 


\section{Többet jelent-e a közösségi informatika a "digitális szakadék" áthidalásánál?}

A „digitális szakadék” vagy „digitális megosztottság” (DM) - angolul: Digital Divide $(D D)$ - hívószóra a Google keresốprogram majdnem egymillió találatot hoz. Ezek közül körülbelül hétszázezer konkrétan az USA-ban és Kanadában (majdnem egyenló megoszlásban), míg háromszázezer a kevésbé fejlett országokban létezó DM-re utal. A DM-nek igen sok különféle meghatározása ismeretes, amelyek közül talán a Whatis hálózati portálon olvasható egyesíti magában a legtöbbet: „A digitális szakadék azt a tényt írja le, hogy a világ lakossága felosztható olyan emberekre, akiknek van, illetve nincs hozzáférésük - és akik rendelkeznek, illetve nem rendelkeznek a szükséges képességekkel - az olyan modern információs technológiák felhasználásához, mint például a telefon, a televízió vagy az internet. A digitális szakadék fennáll a városi és a vidéki területek lakói között. Egy 1999-ben végzett vizsgálat például kimutatta, hogy az interneten elérhetố szolgáltatások igénybevételének 86 százaléka a húsz legnagyobb városra jutott. A digitális szakadék fennáll továbbá a magasabb képzettségúek és a képzetlenek között, a különböző gazdasági helyzetú osztályok között, valamint globális szinten a fejlett és az iparilag kevésbé fejlett nemezetek között is."13

Egy másik definíció még többet mond: „A világ lakosságának egyharmada még soha életében nem bonyolított le egyetlen telefonhívást sem. A világ szegényeinek 70 százaléka távoli vidéki területeken él, ahol az információs és kommunikációs technológiákhoz való hozzáférés még a telefon esetében is gyakran igen ritka adottság. Az információcsere az olyan globális hálózatokon keresztül, mint például az internet, túlnyomórészt angol nyelven folyik, amit a világ népességének csupán egytizede beszél anyanyelveként. A digitális szakadékban ténylegesen a létezố társadalmi-gazdasági egyenlốtlenségek tükröződnek, és a megosztottság kiváltó oka lehet az elégtelen infrastruktúra, a magas hozzáférési költség, a nem megfelelő vagy gyenge politikai rendszer, a távközlési hálózatok elégtelen múködése, a helyileg létrehozott tartalom hiánya vagy éppen az információigényes tevékenységekból eredó gazdasági és társadalmi hasznok elérésére való képességek egyenlőtlen megoszlása is." ${ }^{14}$

A digitális szakadékkal foglalkozó tanulmányok és vizsgálatok sokasága rendszerint nem foglalkozik azzal, hogy a DM „problémájának” vagy egyáltalán a létezésének a megszüntetésére javasolt megoldás, vagyis a „kiszélesített hozzáférési lehetőségek” hogyan fognak a valóságban bármiféle hasznos választ nyújtani azokra a kihívásokra, amelyeket a DM hatásai jelentenek. Nagyrészt figyelmen kívül hagyják a DM hatásait kiváltó okokat, például a növekvớ társadalmi és gazdasági polarizálódás irányába mutató trendeket, melyek értelmében a jómódúak egyre jobb helyzetbe kerülnek, míg a lemaradók még inkább lemaradnak, mivel képtelenek kihasználni az IKT lehetốségeiból adódó előnyöket. Milyen kapcsolat áll fenn például a „hozzáférés” és a jómód vagy a gazdagság létrejötte, illetve a gazdasági fejlődés között, és a „hozzáférés” biztosítása vajon önmagában tesz-e valamit azért, hogy létrehozza ezt a „hiányzó láncszemet”? Ésszerú-e (vagy hasznos-e) a „hozzáférés” szükségességét hangsúlyozni anélkül, hogy

\footnotetext{
${ }^{13}$ http://searchsmb.techtarget.com/sDefinition/0,sid44_gci214062,00.html

${ }^{14}$ http://www.acdicida.gc.ca/ict
} 
ezzel párhuzamosan szorgalmazzuk az IKT használatához elengedhetetlen képzés szükségességét is; vannak-e strukturálisan meghatározott kapcsolatok a „hozzáférés”, illetve a termelési és elosztási rendszerek között; megtörtént-e a „hozzáférés” olyan célterületeinek a kijelölése, amelyek megfelelnek az egyének vagy a közösségek szükségleteinek, a számukra elérhető technikai megoldásokkal? A kérdések sorát még folytathatnánk.

A „hozzáférés” (a hálózathoz, az I/O készülékekhez, a tartalomhoz) természetesen alapvetố és nélkülözhetetlen az IKT mindenfajta felhasználásához és fejlesztéséhez. „Hozzáférés” nélkül igen kevés lehetốség nyílik. Ez a „hozzáférés” azonban - természetéból adódóan - kétarcú: nem mindegy például, hogy egyszerú „hozzáférésról” van-e szó, olyan többfelhasználós környezetekben, mint a teleközpontok és teleházak, vagy pedig az emberek otthonaiban biztosítandó „személyes” hozzáférésre törekszünk. Fontos kérdés továbbá, hogy milyen legyen a mennyisége, a minôsége és a technikai megoldása a hozzáférésnek - széles sáv, WiFi vagy „betárcsázós” kapcsolatteremtés -, melyik fajta „hozzáférés” elegendő „a digitális szakadék áthidalására”, valamint hogyan és mikor leszünk képesek ezt megállapítani.

Felismerhető tendencia nyilvánul meg továbbá a „hozzáférés” mint „technikai” vagy „infrastrukturális” kérdés kezelésére, különösen azok részéról, akik közvetlenül részt vesznek az úgynevezett „fejlesztési programok” kidolgozásában és végrehajtásában. Tágabb értelemben idesorolhatók a kevésbé fejlett országokban érvényesüló politikát befolyásoló nemzetközi intézmények is, amelyek pl. a távközlési hálózatok múködését szabályozó ügynökségeken vagy a fejlesztési politika finanszírozásán keresztül fejtik ki hatásukat. Mindennek eredményeként az „infrastruktúra” terén fellelhetô hiányosságok jobban tudatosulnak, és orvoslásukhoz nagyobb kapacitások állnak rendelkezésre, mint a „hozzáférést” befolyásoló más lehetséges tényezók tekintetében.

Az IKT felhasználása és alkalmazása az „információs társadalom” kiépítésének alapvetố eszközeként azonban messze túlmutat a DM-mel kapcsolatos elemzéseken és vitákon. Magában foglalja annak a vizsgálatát, hogy az IKT-hoz való hozzáférés hogyan és milyen feltételekkel tehetố ténylegesen felhasználhatóvá és hasznossá, vagyis hogyan érhetố el a „hatékony felhasználás” többek között a lakosság marginális helyzetư vagy kirekesztett csoportjaiban és közösségeiben. A legjelentôsebb célok, illetve lehetséges alkalmazások közé tartoznak a fejlesztési stratégiák, valamint az IK'T-nak a helyi gazdasági fejlődés, a társadalmi igazságosság és a politikai részvételi képesség támogatására való felhasználásai, az oktatási és egészségügyi szolgáltatásokhoz való helyi hozzáférés biztosítása, továbbá az információ helyi előállításának és terjesztésének elôsegítése, valamint a helyi kultúrák túlélésének és fenntartható vitalitásának biztosítása.

Míg az IKT-infrastruktúra kiépítésére és hozzáférési pontok (helyi teleházak) létrehozására jelentôs fejlesztési forrásokat fordítanak, ezek közül a kezdeményezések közül kevés irányul az IKT használatához szükséges készségek helyi fejlesztésére, képzési programok szervezésére és fenntartására. Továbbá az olyanfajta IKT-fejlesztések, amelyek lehetôvé teszik a helyi közösségek hatékony részvételét a regionális, országos szintû́, sốt akár globális döntéshozatali folyamatokban (e-Governance), nagyrészt háttérbe szorulnak az elektronikus úton nyújtott hatékony és egyre inkább központilag ellenőrzött kormányzati szolgáltatások (e-Government) megtervezése és megvalósí- 
tása mögött. Az internet mint az aktív és hatékony állampolgári részvétel széles körú kiterjesztésére szolgáló eszköz felhasználásával kapcsolatos korai ígéretek korántsem teljesültek.

\section{Mit jelent a "hatékony felhasználás", és mi a szerepe a közösségi informatikában?}

Konvencionális kontextusokban a „hozzáférés” elsôsorban a fogyasztás és a befogadás oldaláról jelenik meg, nem pedig a termelés és az elosztás oldaláról. Az „információs társadalomban” való részvétel a „hozzáférés” perspektívájából elsősorban a vásárlási képességet, a tartalmak letöltését és az egyik vagy másik külsóleg létrehozott hálózati honlappal való passzív interakciót jelenti. A DM ilyenfajta áthidalásának célja nyilvánvalóan annak biztosítása, hogy a fogyasztói javak és az elektronikus közvetító eszközök felhasználásával szervezốdố piacok fogyasztójaként mindenki elérhetố legyen.

Az IKT társadalmilag igazságos felhasználásának biztosítására törekvố szereplôk esetében a „hozzáférés” mint első számú cél meghatározását illetôen figyelembe kell venni a Clement és Shade által megfogalmazott kérdéseket: „Hozzáférés mennyiért, mi célból, kinek a számára és mihez?” Ezeknek a kérdéseknek a tüzetes megvizsgálása nélkül a „hozzáférés”, ahogy a DM kontextusában leggyakrabban felvetődik, egyszerúen csak a lehetôségek biztosítását jelenti az interneten keresztül elérhető szolgáltatások, javak és információk passzív fogyasztásához.

$\mathrm{Az}$ internet mint termelési eszköz (vagy még tágabban értelmezve: mint átalakulást kiváltó eszköz) eszméje, sốt valójában mint az információs kor központi termelési eszköze az olyan gazdaságok számára, amelyek alapvetôen az IKT platformjára támaszkodnak, elvész. A „termelôi státus” ebben a kontextusban csupán kevesek számára van fenntartva. A gyakorlatban ez úgy értendô, hogy csupán azoké, akik a nagyvállalatok vagy kormányzatok számára dolgoznak, vagy a technikailag fejlett országokban élnek, és azoknak a közösségeknek a tagjai, amelyek nem csupán a fogyasztáshoz, hanem a termeléshez szükséges speciális képzettséggel és készségekkel is rendelkeznek a technológiai környezetben. Ezekben a kontextusokban a lehetôség (és az abból adódó haszon), hogy valaki termelő és fogyasztó egyaránt lehet, csupán azok számára van fenntartva, akik nem egyszerúen csak „hozzáféréssel” rendelkeznek, hanem abban a privilegizált helyzetben vannak, hogy részt vehetnek mindazoknak az alkalmazásoknak és használati módoknak a megtervezésében és fejlesztésében, amelyekhez a szóban forgó „hozzáférés” utat nyit.

A kulcstényezố mindebben nem a „hozzáférés” biztosítása akár az infrastruktúrához, akár a végfelhasználói terminálokhoz (ami a hardvert illetốen egyenértékú lenne „a szakadék áthidalásával”). Inkább annak van jelentősége, hogy a már megteremtett hozzáféréssel együtt jár-e a tudás, a készségek, valamint a támogató szervezeti és társadalmi struktúrák megléte is az e-technológia és a hozzáférés hatékony kihasználásához a társadalmi és közösségi célok elérése érdekében. Sót, még az IKT útján elérhetô szolgáltatások és javak fogyasztásának kontextusában is az a helyzet, hogy ha nem fordítunk elegendő figyelmet arra a módra, ahogyan a hozzáférést biztosítják, tervezési vagy más hibák következtében sokan vagy akár a legtöbben nem lesznek képesek kihasználni az 
elérhetố lehetốségeket. Az igazi kihívást tehát az jelenti, hogy nem egyszerúen „hozzáférést”, hanem „hatékony hozzáférést” vagy „, használatot” kell biztosítani, vagyis olyan hozzáférésre van szükség, ami hatékony eszközként felhasználható az egyének által önmaguk elé állított célok beteljesítésére.

Az információs és kommunikációs technológiáknak sajátos természetük van. Miután elérhetôvé váltak, könnyen túlmutathatnak az egyszerü tartalomszolgáltatáson (azok számára, akiknek „hozzáférésük” van), és ezen túlmenően döntő szerepet játszhatnak azáltal is, hogy a „tartalom” termelésének, elosztásának és értékesítésének az eszközeivé válnak lokálisan vagy globális szinten. Továbbá - a tartalmon kívül - biztosítják a termelés, az elosztás, az értékesítés és a szolgáltatás infrastruktúráját bármilyen tevékenységi területen, amelynek jelentôs információs, tudásjellegú vagy tanulási komponense van. Világosan látnunk kell, hogy az információ korának „sátáni malmai” éppen az információs és kommunikációs technológiák, ám - ellentétben múltbeli elődeikkel - ezek a „sátáni malmok” egyszersmind lehetôséget is teremtenek a széles körú felhasználás és alkalmazás számára.

Az IKT „hatékony felhasználása” a következóképpen definiálható: képesség és lehetốség az IKT sikeres alkalmazására az egyénileg vagy másokkal együttmúködve meghatározott célok elérése érdekében. Ez magában foglalja az alábbiakat:

1. Információs rendszerek. Milyen távközlési szolgáltatási infrastruktúrára van szükség a választott alkalmazás támogatásához? Melyek a megfelelő és megkívánt sávszélességi paraméterek, amelyekkel a széles sávú, „betárcsázós”, WiFi, múholdas vagy más hálózati távközlési szolgáltatásoknak rendelkezniük kell? Mennyi erốforrás ráfordítását igényli annak a biztosítása, hogy a támogató technológiai infrastruktúra elérhetố legyen, a kívánt cél eléréséhez szükséges formában és minőségben (sávszélesség, hibaszázalék stb.)?

2. Inputloutput berendezések. Milyen berendezésekre van szükségük a felhasználóknak bizonyos tevékenységek elvégzéséhez? Szükség van-e például számítógépekre az információ feldolgozásához, digitális személyi asszisztensre (Personal Digital Assistant, PDA) a mobil hozzáféréshez, illetve nyomtatókra a szövegek elôállításához?

3. Eszközök és támogató rendszerek. Milyen szoftverekre, fizikai támogató rendszerekre, protokollokra és szupport szolgáltatásokra van szükség? Nagy mennyiségú környezeti adat alakulásának nyomon követéséhez szükség lehet például adatbázisokra, amelyekre a környezettel foglalkozó csoportok támaszthatnak igényt, míg nyomtatott tankönyvek megléte követelmény lehet ahhoz, hogy a tanárok hatékonyan fel tudják használni az interneten keresztül elérhetô oktatási rendszerekben megtalálható tartalmakat.

4. Tartalomszolgáltatás. Milyen speciálisan megtervezett tartalmakra van szükség bizonyos alkalmazási területeken? Melyek a helyileg meghatározott kontextuális és felhasználhatósági követelmények (nyelv, dizájn, írástudási szint, lokalizált referenciák, kapcsolatok stb.) az adott tartalom hasznosításához? A hatékony felhasználás olyan tartalmat tételez fel, amelyet kifejezetten a „hatékonyságra” törekedve, megbízható módon és a végfelhasználók bizonyos típusai számára közvetlenül felhasználható nyelvi formátumban terveztek meg. 
5. A szolgáltatások biztositása és elérhetósége. Milyen típusú társadalmi és szervezeti infrastruktúrára, vagyis a helyi társadalmi hálózatokkal, szakemberekkel és képzési lehetôségekkel kialakítandó kapcsolatrendszerre van szükség a szóban forgó speciális alkalmazáshoz? A hatékony felhasználás sokféle alkalmazási területen megkívánja nemcsak a technológiai, hanem a társadalmi infrastruktúra meglétét is. Így például az e-egészségügyi szolgáltatások hatékony felhasználásához a távoli területeken nem elégséges csupán a fizikai infrastruktúrához, az input-output berendezésekhez és ezeken keresztül az információhoz való technikai hozzáférés biztosítása és a szolgáltatások adekvát megtervezése. Emellett szükség van olyan egészségügyi ellátási infrastruktúrára is, amelybe beletartoznak az egészségügyi szolgáltatók, a helyi asszisztencia és a közösségi támogató rendszerek is, vagyis nélkülözhetetlen a szolgáltatások társadalmi szervezeti struktúrája, ami a kapott információkat és szolgáltatásokat összekapcsolja a helyi szervezeti struktúrával és a kapcsolódó szolgáltatási és támogató rendszerekkel.

6. Társadalmi segitség. Milyen helyi, illetve regionális hatósági támogatás vagy társadalmi eróforrás, közösségi és környezeti infrastruktúra, képzés és animáció szükséges a kívánt alkalmazás vagy felhasználás helyi megvalósításához? Az IKT-re alapozott szolgáltatások hatékony felhasználása gyakran megkívánja különféle támogatók igénybevételét, mivel spontán módon a szolgáltatás valószínúleg nem vezethetố be hatékonyan. Ahhoz, hogy a szolgáltatás ténylegesen felhasználható legyen, szükség lesz összehangolt tervezésre, képzésre (valamennyi szinten), továbbá a támogató struktúrák aktivizálására, és általában természetesen szükség lesz a helyi vezetés bevonására is.

7. Kormányzati feltételek. Milyenek a megkívánt pénzügyi, szabályozási és politikai feltételek az országos jogi és szabályozási rendszerben az adott alkalmazás kormányzati támogatásához vagy akár szélesebb körú bevezetéséhez? A hatékony felhasználáshoz sok esetben nélkülözhetetlen a kedvezố pénzügyi struktúra, a támogató (vagy legalábbis nem akadályozó) jellegú jogi vagy szabályozási rendszer és a politikai támogatás. Így például számos elốre fizetéses egészségügyi rendszerben - mind magán-, mind állami egészségbiztosítás esetén - jelentôs korlátozást az e-egészségügyi szolgáltatások hatékony felhasználása szempontjából, ha olyan pénzügyi rendszer van érvényben, amely nem biztosítja a helyileg nyújtott elektronikus egészségügyi ellátási szolgáltatások költségeinek visszatérítését a helybeli (vagy nem helybeli) felhasználók számára.

Amikor a hatékony felhasználás fogalmára utalunk, jelentôsen kibóvítjük vizsgálódásunkat a fejlődés szolgálatába állítható IKT-eszközökön túl is, a „fejlesztési folyamat" egészére helyezve a hangsúlyt, beleértve az infrastruktúrát, a hardvert, a szoftvert és a társadalmi szervezési elemeket: mindezek együttesen szükségesek a fejlődés eléréséhez. Világos, hogy a „hatékony felhasználás” előfeltétele a „hozzáférés”. Az IKT "hatékony felhasználása" azonban - a tervezés és a fejlesztés folyamatában szem elôtt tartandó célként - nem szükségképpen jelenik meg a DM-ból adódó gondok feltárására, illetve megoldására tett konvencionális erốfeszítésekben.

A hatékony felhasználással kapcsolatos kérdések továbbá jelentôs mértékig kontextusfüggő́ek, vagyis ami az egyik kontextusban hatékony felhasználásnak számít, az 
nem feltétlenül lesz az valahol másutt. A hatékony felhasználás meghatározásakor általában az egyéni használatra, a felhasználóra vagy a felhasználói közösségre kerül a hangsúly. A hatékony felhasználásra irányuló stratégiák megtervezésére és kidolgozására csakis a folyamatos párbeszéd adhat csak lehetốséget, amelyben az egyik oldalról az egyenlő́tlenségek megszüntetésére vagy csökkentésére törekvố szereplók, a másik oldalról pedig azok a végfelhasználók vesznek részt, akik a legvilágosabban képesek átlátni, hogy az adott helyi kontextusban mely alkalmazások vagy felhasználási módok lehetnek a leghasznosabbak.

Meg kell jegyezni, hogy a fentieket kizárólag mint elvi megfontolásokat fejtettük ki. A valódi világban a technológia elsajátítási és használatba vételi folyamatának „éloové tételéhez" mindig szükség van a helyi közösség aktív részvételére. Meg kell nyilvánulnia a közösség „húzóerejének” is, lehetóleg megelôzve a „felülról lefelé” irányuló külsố „nyomás” meglétét. Többen rámutattak, hogy már jóval a tényleges fejlesztési programok beindulása elốtt igyekezni kell létrehozni ezt a helyi „húzóerôt”, mivel a közösségek vagy a helyi felhasználók sok esetben nincsenek tisztában azzal, hogy milyen típusú lehetôségek válnak elérhetővé az IKT révén. Igen fontos szerephez jut tehát a közösségfejlesztés, a helyi közösség tájékoztatása, motiválása és aktivizálása.

\section{Többet jelent-e a közösségi informatika, mint a közösségi hálózat?}

A Merriam Webster szótár a közösség fogalmára a következő definíciókat adja: „egyének egységes csoportja”, illetve „egy bizonyos területen élő, közös érdekekkel összekapcsolt emberek”. Ugyanitt a hálózat meghatározása így hangzik: „számítógépek, terminálok és adatbázisok közösségi kommunikációs kapcsolatokkal összekötött rendszere". A közösségi hálózat mibenlétére tehát - e két meghatározás kombinációjából - az alábbi definíció adódik: „Közösségi hálózatokról akkor beszélünk, ha közös érdekekkel bíró emberek valamilyen egységes csoportja kommunikációs kapcsolatokkal összekötött számítógépek, terminálok és adatbázisok rendszerét használja fel.” Ha valamivel tágabb definíciót keresünk, amely a technikai megfogalmazás mellett magában foglalja a fenti variációkból kivonható társadalmi értékeket is, akkor a következóhöz jutunk: „A közösségi hálózat olyan, helyi alapokon kiépüló és helyi erókre támaszkodó kommunikációs és információs rendszer, amelyet a közösség fejlesztésére és életének gazdagítására hoznak létre." A közösségi hálózat (Community Network), illetve - folyamatként szemlélve - a közösségi hálózatépítés (Community Networking) kifejezéseket már sok éve elfogadott terminusként használják számos országban és több ezer IKTprojektben, amelyekben kombinálódik a földrajzi meghatározottság és az online kontextus attól függó arányban, hogy az adott esetben melyik mekkora szerepet játszik. A fogalom meghatározására irányuló kísérletek túlnyomó többsége azonban a földrajzi meghatározottságot tekinti alapvetốnek. A Közösségi Hálózatépítési Egyesület (Association for Community Networking) kiadványa, amelyet az egyesület megalakulásakor tettek közzé, így fogalmaz: „Közösségi hálózatról akkor beszélhetünk, amikor az emberek és szervezetek helyi szinten a megfelelő információs és kommunikációs rendszerekre támaszkodva együttmúködnek a problémák megoldásában és új lehetôségek megte- 
remtésében. A közösségi hálózat helybeli bázison helyi erók által fenntartott kommunikációs és információs rendszer." ${ }^{15}$

A KI kontextusában jelenleg a közösségi teleházak azok a helyszínek, ahol - különösen a kevésbé fejlett országokban - a legtöbb közösség tagjai találkoznak az IKT-eszközökkel, amelyek közvetítésével közösségi folyamatok szerveződhetnek. Az internetkávézók vagy más, díjfizetés ellenében bárki számára internet-hozzáférést nyújtó üzleti vállalkozások természetesen sok helyen versenghetnek a teleházakkal, és elófordulhat, hogy ezekben található meg az egyetlen internet-hozzáférési lehetôség az adott közösségben. A teleházak és az internetkávézók közötti különbség természetesen nem csupán abban áll, hogy az egyik „ingyenes”, a másik pedig „fizetôs”, ugyanis egyes teleközpontok szintén díjat vagy más hozzájárulást kérnek a szolgáltatások igénybevételéért. Fontosabb, hogy a teleház olyan hely, ahol a közösségi tevékenységeket támogató akciók, szolgáltatások és célzott programok valósíthatók meg, míg az internetkávézók pusztán olyan helyek, ahol az egyének interakcióba léphetnek egymással az interneten keresztül, melynek célját - legalábbis elméletileg-csak ók maguk ismerik.

Ez a különbség annyit jelent, hogy a teleházaknak többnyire saját személyzetük van, költségvetéssel, esetleg szoftverrel és más forrásanyagokkal is, amelyek az IKT révén nyújtott programok és szolgáltatások különféle fajtáinak támogatására készültek, vagy elősegítik a teleházon keresztül lehetôvé vált hozzáférés hatékony felhasználását egy szélesebb kört érintő társadalmi vagy gazdasági célok és tevékenységek megvalósítása érdekében. Így a teleház mint helyszín nem egyszerúen csak a „hozzáférés” helye, hanem olyan eszköz, amelyen keresztül a hozzáférés a szervezeti, társadalmi vagy más célok elérésében érdekelt egyéb csoportokat is kiszolgáló kontextusban valósul meg, és a teleházak speciális kialakítása, személyzete, múködtetése és fejlesztése éppen ennek támogatására szolgál.

A KI perspektívájából igen fontos, hogy a teleház múködését milyen mértékben alakítják és szervezik úgy, hogy céljait - az IKT használatán keresztül - a tágabb közösség valós érdekeit képviselve valósítsa meg. Például az olyan teleházak, amelyek külsốleg irányított speciális szolgáltatásokat vagy programokat kívánnak támogatni, ideértve az e-kormányzati szolgáltatásokat is, szintén fontosak a közösségek számára. A hosszú távú helyi fejlődés szempontjából azonban természetesen még nagyobb jelentốségú az a támogató szerep, amit az ilyen teleházak a folyamatban levơ közösségi folyamatok részeként töltenek be oly módon, hogy a szolgáltatásokat a helyi kapacitások figyelembevételével választják ki és szervezik meg, miáltal valószínúbbé válik, hogy a központok helyi erốforrásokat vesznek igénybe, és így biztosítják hosszú távú fenntarthatóságukat.

A teleházak hosszú távú fejlôdésében és hatékony felhasználásában kulcstényezố továbbá a hálózati kapcsolatok kiépítése más teleházakkal (és rajtuk keresztül más közösségekkel). Az ilyen nagy kiterjedésû önálló közösségi hálózatok kifejlődésén keresztül nyílik lehetôség a folyamatos önfejlesztésre és önszervezésre a szolgáltatások egész sorában, különösen ott, ahol a helyi szervezés és vezetés biztosítja a program optimális hatékonyságát. Ennek eléréséhez kihasználható a nagy méretek gazdaságossága (economy of scale). Nem véletlen, hogy éppen az ilyen hálózatok létrehozása ré-

${ }^{15}$ Community Networking. 1998. Vol. 1., Issue 1. January-February, 1. 
vén válik lehetôvé az effajta közösségi alapú kezdeményezések összekapcsolása a politikai célkitû́zésekkel, ami egyben a széles körû́ társadalmi mozgósítás új folyamatait indíthatja meg.

\section{Beszélhetünk-e "vezeték nélküli közösségi informatikáról"?}

Az úgynevezett ,vezeték nélküli közösségek” közösségi létével és az ilyen közösségekre vonatkozóan értelmezett közösségi informatika létével kapcsolatos kérdéseket többféle szempont és a körülmények figyelembevételével érdemes mérlegelni. Ezek a kérdések ugyanis nagyrészt abból a sajátságos helyzetból adódnak, hogy a vezeték nélküli kommunikáció korai innovátorai közül sokan, akik önmagukat „közösségi hálózatépítóknek" nevezték, keveset tudtak a hagyományosabb, már hosszabb ideje funkcionáló közösségi hálózatokról annak ellenére, hogy többségüket a közösségi hálózatépítés korai úttörốihez hasonló háttér - progresszív politikai beállítottság, egyetemi végzettség, technikai szakértelem és fiatal életkor - jellemezte. ${ }^{16}$

A vezeték nélküli közösségi informatika problematikájának átgondolását nehezíti, hogy a vezeték nélküli kommunikáció infrastruktúrája szükségképpen virtuális és a helytól független, s így vezeték nélküli kommunikáció útján természetszerúleg különösen nehéz a közösségi összetartozás, a közösségteremtéshez szükséges normatív integráció megvalósítása. A vezeték nélküli felhasználók egyszerúen azok, akik vezeték nélküli kapcsolat útján férnek hozzá az internethez, és nincs szükségük más felhasználókhoz fúzốdó kapcsolatok és összeköttetések kialakítására sem az interneten, sem pedig az internetszolgáltatón (Internet Service Provider, ISP) keresztül. Mivel azonban egyesek megállapították azt a tényt, hogy a vezeték nélküli összeköttetésnek is van bizonyos mértékú térbeli horgonyszerepe (az egyének valamilyen földrajzilag meghatározott „forróponton” keresztül jutnak hozzáféréshez), ez megnyitja a lehetôséget a kölcsönös kapcsolatteremtéshez az adott ISP-nek az adott helyeken véletlenszerúen megjelenó, egymás számára névtelen felhasználói között.

Egyes korai ISP-k, majd az AOL (America Online) is hasonló nehézségekbe ütközött (és ugyanakkor hasonló lehetôségekkel találkoztak), amikor internetszolgáltató szerepüket arra használták fel, hogy virtuális strukturáló tényezóként lépjenek fel, igyekezve az általuk virtuálisan közbeiktatott struktúra keretei közé olyan ösztönzô jellegú tartalmi elemeket is becsempészni, melyek segítségével rávehetik a felhasználókat a struktúrával mint a virtuális tevékenységeik alapját képezó rendszerrel való együttmúködésre. Ez a fajta együttmúködés azonban nem a nyílt internet „soktól sokhoz" típusú kapcsolatrendszerében valósul meg: az egyes felhasználók - az adott ISP-tól vagy a vezeték nélküli forróponttól függóen - inkább a hozzájuk hasonló felhasználókkal lépnek interakcióba. Az, hogy ez a forrópont felhasználói esetében csak bizonyos mértékig körülhatárolt földrajzi térben (a forrópont vezeték nélküli elérhetôségének határai között) valósulhat meg, lehetôséget ad az ISP vagy a forrópont múködtetôjének arra, hogy elősegítse a vezeték nélküli felhasználók kölcsönös kapcsolatainak

${ }^{16}$ http://www.seattlewireless.net/ 
kialakulását, és ezen keresztül bizonyos „közösségi” interakció létrejöttét közöttük. Az $A O L$ esetében ez a korlátozott mennyiségú interakció abban merül ki, hogy hirdetéseket juttatnak el a felhasználókhoz (miközben azok a közbeiktatott információkra fordítják a figyelmüket), a montreali Ile Sans Fils (ISF) esetében pedig városfejlesztési programok elốmozdítását célozza.

Az, hogy érdemes-e hozzákezdenünk a vezeték nélküli közösségi informatika konceptualizálásához és kidolgozásához, attól függ, hogy ez a fajta közbeiktatott szerep, illetve a forrópontok és a közöttük kialakuló kapcsolatok mennyiben képezik társadalmi mozgósítás vagy közösségi szolgáltatások alapját.

\section{Melyek a közösségi informatika előtt álló kihívások és lehetőségek?}

A KI elốtt nyitva áll a lehetôség, hogy alapot nyújtson és irányt mutasson azoknak a módoknak az újraátgondolásához, ahogyan a közösségek birtokba veszik a technológiát, irányítsa az információs rendszerek fejlesztési célok érdekében szorgalmazott bevezetését, továbbá - és talán ez a legfontosabb - vezetô szerepet játsszon a közösségek jelentôségének fokozásában a technológiára támaszkodó modern társadalomban. A KI egyik legalapvetốbb funkciójaként kritikát képvisel a fejlesztés konvencionális megközelítéseivel szemben, megfordítva az IKT társadalmi felhasználásainál alkalmazott szokásos, felülról lefelé irányuló módszert. Ehelyett az alulról jövő kezdeményezésekre helyezi a hangsúlyt, ami biztosíthatja a kollektívák és az egyének lehetôségeinek kibővítését egyaránt, továbbá új utat kínál az információs társadalom demokratizálásához, arra használva fel az IKT eszközeit, hogy a hatalmat és a döntések felelősségét a központi intézmények helyett inkább a közösségek kezébe juttassa.

A KI képviseli továbbá azt a megközelítést, amely a jövốben közép- és hosszú távon az egyetlen járható (fenntartható és költséghatékony) utat fogja jelenteni az információigényes szolgáltatások megszervezésére és széles körú elterjesztésére. Ennek belátásával elmondható, hogy a KI elótt mind a gyakorlatban, mind a tudományos kutatás és fejlesztés terén kiemelkedô lehetôségek állnak. A magam részéról úgy vélem, hogy a KI párhuzamosan fejlődhet a vezetói információs rendszerek (Management Information Systems) szakterületével. Az egyetemeken és fóiskolákon például megvan a helye az információval és az informatikával foglalkozó, „Információs tanulmányok” vagy „Információs rendszerek" címmel futó tanulmányi kurzusokban, ám erôsebben hangsúlyozva a „gyakorlati” komponenst, ami ebben az esetben összekapcsolható például a szociológiai és/vagy közigazgatási képzéssel, az IT tervezésével és fejlesztésével foglalkozó kurzusokkal, valamint a szolgáltatástervezési és fejlesztési tanulmányi programokkal.

A közösségi informatika ugyanakkor sokféle kihívással néz szembe. Az eloótte álló legnagyobb közvetlen kihívást talán az intézményesedéssel összefüggó problémák jelentik. A KI ugyanis afféle „kívülálló” jelenségként indult, és zászlaja alatt a „bevett” tudományos szakágak keretein kívül dolgozó kutatók és gyakorlati technikai szakemberek gyưlttek össze. Múvelói különösen olyan szakemberek lettek, akik elégedetlenek voltak a maguk tudományágaival, mert azok nem voltak hajlamosak számításba venni az IKT-val összefüggó lehetôségeket és kockázatokat, különös tekintettel arra a hatásra, 
amit az új technológiák a marginalizált csoportokra és a fejlôdő világ lakosságára gyakorolhatnak. A KI kutatói azonban - a legtöbb hasonlóan kívülálló, „tudományközi” érdeklődésú szakemberrel ellentétben - nem szükségképpen valamiféle „kritikai” alapállásból indultak ki, vagyis miközben kritikusak lehettek a saját tudományterületükkel szemben, akár intézményi, akár konceptuális szempontok alapján, sokakat közülük vonzottak és lelkesítettek a tágabb értelemben vett társadalmi változásokban rejló lehetôségek, amelyeket az IK'T szerepében véltek felfedezni. Így tehát nem pesszimistán viszonyultak a folyamatban levő változásokhoz, hanem sok változásban meglátták (legalábbis potenciálisan) a jobb helyzet megteremtésének lehetőségét, és hozzá akartak járulni a saját munkájukkal is ahhoz, hogy ezek a fejlemények a kívánatos irányban bontakozzanak ki.

Emlékezetem szerint Randall Pinkett volt az, aki - egy Colorado Springs-i rendezvény alkalmából - elôször vetette fel, hogy a KI nem tudományág és nem is gyakorlati szakmai terület, hanem inkább „mozgalom”, és azóta is foglalkoztat ez a gondolat. Mások is hasonló álláspontra jutottak. Úgy vélem, hogy a KI-nek csakugyan megvannak a mozgalmak bizonyos jellemvonásai, legalábbis annyiban, hogy megnyilvánul benne bizonyos mértékú ideológiai állásfoglalás, a tudományos következetességre való törekvés elutasítása, és sokan a „doktrína” ellen lépnek fel. Ennél is fontosabb, hogy a KI központi magját az a vízió alkotja, hogy a világ milyenné válhatna a technológia révén megerősített közösségekkel, a társadalmi és a politikai hatalmi viszonyok ezzel együtt járó átstrukturálódása nyomán, és hogy ez milyen körülmények között és hogyan érhetô el - a technológia legszélesebb körű bevezetése és társadalmi birtokbavétele útján, alulról felfelé irányuló kezdeményezésekkel. Megnyilvánul továbbá az a felfogás is, hogy a KI szemléletébe bele kell tartoznia a morális (sốt akár politikai) perspektívának is, tehát nem csupán bizonyos fogalmak, modellek és technikák készletéról van szó, hanem erkölcsi alapú irányzatról: a KI múvelése nem pusztán egy tudományos irányvonal egyszerú elfogadását, hanem egy meghatározott irányú, céltudatos és együttmúködésre orientált kutatási programhoz való csatlakozást jelenti.

\section{Hosszú távon milyen hatással járhat a közösségi informatika, és ez miért fontos?}

A közösségi informatika egyike azoknak az újonnan felbukkanó tudományközi vagy határterületi megközelítéseknek, amelyek elsősorban a fejlődés bizonyos problémáira vagy bizonyos döntések következményeire koncentrálnak. Ezek nagy része összefügg a technológiával - idesorolható például sokféle szerepjáték és a számítógépes modellezés is -, de talán a KI a legambiciózusabb közöttük, mivel átlép a tudományágakat elválasztó határvonalakon olyan mértékben, hogy nemcsak a viselkedési jelenségekre, hanem ezen túlmenóen a társadalmi dimenziókra is figyelmet fordít.

A KI mint gyakorlati cselekvési terület, véleményem szerint, gyorsuló fejlődésnek néz elébe, és jövôje hosszú távon minden bizonnyal biztosítva van. Mivel a helyi közösségek számára kidolgozott (és azok által birtokba vett, illetve a gyakorlatban alkalmazott) technikai erôforrások és stratégiák rendelkezésre bocsátása annyira kézenfekvô megoldást kínál a fejlődés fenntartására, és olyan nyilvánvalóan felsóbbrendú a társadal- 
mi és gazdasági fejlesztési célok helyi szinten történố megvalósítására más, felülról lefelé irányuló módszerekkel törekvő megközelítésekhez képest, hogy a magam részéról úgy látom, számos progresszív szemléletủ fejlődő ország kontextusában ténylegesen a KI fogja jelenteni a normát. A helyi közösségek IKT-eszközök révén elérhetố megerősödése természetesen fontos eleme az IKT-használat általános elterjedésének, és ezt nem mindig kedvező fényben látják a meglevő hatóságok. Az, hogy ezt a problémát az egyes országok hogyan fogják kezelni, egyelốre még a jövố nyitott kérdése. Igen valószínúnek tûnik azonban, hogy a számítógépesítés során végbemenố nagyszabású társadalmi átalakulási folyamatoknak erre az aspektusára a politikai intézmények részéról adott válasz pozitív lesz. Egyre nyilvánvalóbbá válik ugyanis az a szükséglet, hogy a lakosság periferikus helyzetben levő szélesebb tömegei is beágyazódjanak a társadalom és a gazdaság szövetébe, és mivel ez a folyamat egyértelmúen összekapcsolódik az IKT általános elterjedésével, világosan felismerhetố, megalapozott trend mutat abban az irányban, hogy a közösségi informatika az IKT használatba vételének és gyakorlati alkalmazásának pilléreként az alapvetố politikai keretekbe illeszkedve töltheti be funkcióját.

Arra a kérdésre, hogy a közösségekben a KI jegyében számukra elektronikus úton nyújtott szolgáltatások révén nagyobb mértékú átalakulás tanúi leszünk-e, véleményem szerint kevésbé nyilvánvaló a válasz. A kívánatos átalakulás valamennyi szinten és valamennyi fejlődési fokozatban befolyásolja a szolgáltatási rendszert, és bizonyos mértékig megkívánja a szolgáltatások, valamint az azokat támogató szakmai struktúrák újraátgondolását is. Ha az oktatást vesszük példának (de vehetnénk az egészségügyi ellátást vagy más általános állami szolgáltatást is), akkor az a perspektíva tárul fel, hogy a szolgáltatás elsô vonalában az egyensúly elbillenhet a közösségi alapú tanulás felé, felhasználva a tudás közösségi forrásait és személyi bázisát is. Eljuthatunk oda, hogy a szakemberek munkáját nyomon követô és ellenốrzô bürokratikus struktúrák átadják a helyüket a közösségi folyamatoknak, amelyekben a szakemberek nem csupán közvetlen szolgáltatóként múköönnek, hanem a szolgáltatások biztosításához szükséges helyi folyamatok támogatóivá válnak, legalábbis a készségek és a követelmények alapvetôbb szintjén, ahol mindez drámai változásokkal jár együtt.

Az egészségügyi ellátás, véleményem szerint, speciális kérdéseket vet fel, mivel az egészségügyi ellátás költségei egyre kevésbé támogathatók államilag, és egyre nyilvánvalóbbá válik, hogy - legalábbis az alapvetố szolgáltatások szintjén - alacsonyabb költségú alternatívákat kell találni. A közösségi alapú szolgáltatások keretében nyújtott egészségügyi ellátás, amelyben a szolgáltatókat speciálisan megtervezett tartalom és szoftver támogatja, véleményem szerint szinte nélkülözhetetlenné válik, kezdetben fóként a legkevésbé fejlett országokban, de késóbb valószínúleg a fejlettebbekben is. Jól érzékelhető jelzések utalnak arra, hogy az egészségügyi ellátás alulról felfelé irányuló megközelítéssel biztosítható általános szintje ily módon drámai mértékben javulhat. A nehézségek természetesen a jelenlegi szakmai és bürokratikus struktúrák elsáncolódott pozícióiból és érdekeiból fakadnak, mivel ezek mutatják a legnagyobb ellenállást a változásokkal szemben, és bármilyen változás nagyrészt csupán az ezekból a körökból érkezố ellenállás legyoózése útján valósítható meg.

Az a kérdés pedig, hogy a közösségi informatika „fontos-e”, és ha igen, miért és kinek, egyenesen az információs társadalom problematikájának a központi magjához 
vezet el bennünket: azokhoz a választási lehetôségekhez, amelyek elôttünk állnak a további fejlődés fő irányvonalának meghatározása terén. Meggyớződésem szerint sokakban vitathatatlanul fennáll a vágy az IKT eszközeinek felhasználására a közösségek fenntartása, kiterjesztése és hatékonyabbá tétele érdekében, mivel ezt bizonyítja a társadalmi hálózatépítéshez kifejlesztett szoftverek sikere is, amelyek bizonyos mértékig éppen ezeket a célokat szolgálják. Ugyanilyen fontos továbbá az a széles körben terjedő felismerés is, hogy az IKT eszközök csupán alulról felfelé irányuló bevezetésükön és hatékony közösségi felhasználásukon keresztül válhatnak hasznos részévé a gazdasági és társadalmi fejlődés folyamatának.

A KI azért fontos, mert nem csupán cselekvésre van szükség, hanem egyszersmind annak a szisztematikus végiggondolására és megértésére is, amit cselekszünk. E megértés hiányában a siker a legjobb esetben is csak véletlenszerúen valósulhat meg, a legrosszabb esetben pedig - ha a hibákból nem tanulunk, tehát azok megismétlódnek, valamint ha a sikereket nem ragadjuk meg, és nem építkezünk rájuk távolabbi horizontok elérése érdekében - csak elvesztegetjük az időt és erőforrásainkat, és a közösségi informatika koncepciója hitelét veszti. 